\title{
An overview on individual criminal liability for crime of aggression
}

\author{
Asif $\operatorname{Khan}^{1 *} \mid$ Shaukat Hussain Bhatti ${ }^{2} \mid$ Abid Shah $^{1}$
}

1. School of Law, Zhengzhou University, Zhongyuan, Henan, China.

2. Department of Law, Times Institute-University, Multan, Pakistan.

*Corresponding Author Emails: drasifphdlaw@yahoo.com | drasifkhan@gs.zzu.edu.cn

\begin{abstract}
Over the last few years, international criminal law has included an internationally recognized definition of the crime of aggression. One may sight the respective portion from part two (jurisdiction, admissibility and applicable laws) article 08 of the respective document. The purpose of this research represents the historical background of individual criminal responsibility under international law and the concept of individual criminal accountability for the crimes falling under the ambit of international criminal law committed by persons. Whereas the idea of how an individual could be brought to justice, for one of the core crimes of ICC's statutes, i.e., crime of aggression, was recently adopted and envisaged into Rome statutes, after the Kampala conference 2010. The concept of individual criminal responsibility for the crime of aggression faced many difficulties in at-least adopting its proper definition, which was leftover for future when Rome statue was formulated. To keep pace, this concept needs further evolution. Such an evolution demands such a condition wherein while granting the characteristics of adaptability with the contextual conditions and principles of criminal law. This article explores the anatomy of the crime of aggression and highlights issues that remain to be resolved.
\end{abstract}

Article History

Received:

April 3, 2021

Last Revised:

June 18, 2021

Accepted:

June 22, 2021

Published:

June 26, 2021

Keywords: International Law, International Criminal Court, crime of aggression, criminal responsibility, individual criminal responsibility.

\section{How to Cite:}

Khan, A., Bhatti, S. H., \& Shah, A. (2021). An overview on individual criminal liability for crime of aggression. Liberal Arts and Social Sciences International Journal (LASSIJ), 5(1), 432-442 https://doi.org/10.47264/idea.lassij/5.1.28

Publisher's Note: IDEA PUBLISHERS (IDEA Journals Group) stands neutral with regard to the jurisdictional claims in the published maps and the institutional affiliations.

Copyright: () 2021 The Author(s), published by IDEA PUBLISHERS (IDEA Journals Group). This is an Open Access article published under the Creative Commons Attribution-NonCommercial 4.0 International License (http://creativecommons.org/licenses/by-nc/4.0/) 


\section{Introduction}

An attack on the foundations of international relations cannot be regarded as anything less than a crime against the international community, which may adequately vindicate the integrity of its fundamental compacts by punishing aggressors. We, therefore, propose to charge that a war of aggression is a crime, and that modern International Law has abolished the defense that those who incite or wage it is engaged in a legitimate business. Thus, may the forces of the law be mobilized on the side of peace (McDougall, 2021). Several forums well-define the term "aggression" as: aggression is a forceful action or procedure like an unprovoked attack with the essence to dominate or master on others (Dictionary, 2020). In a simple view, it is the breach of international law by the states, the state involved in the aggression is termed as an aggressor. Several efforts have been made to enclose aggression into a proper definition and what acts tantamount to aggression. The attempt of the United Nations Organization Forum to propose and adopt a resolution defining the term "aggression" in transactions is the use of military force by a State against the sovereignty, territorial integrity, or political independence of another country or in a manner inconsistent with the Charter of the United Nations (UN Resolution 3314 (XXIX), 1954). The above-cited resolutions' specific primary attributes, it neither explains the conditions in which the above-cited acts tantamount to aggression and it nor emphasizes the exceptional circumstances that would make the enumerated acts defensive rather than offensive. The definition has not yet been used as a reference by the United Nations to describe the actions of the nation as violence. The act of definitively defining aggression and of drawing a generally appropriate definition is not a simple task, since it is clear from the Rome Statute that it confers jurisdiction over the crime of aggression on the ICC, which enables the parties to the conflict to define the crime in order to depend on the jurisdiction of the institute concerned (Heller, 2020, art. 05).

One of the main reason behind the non-compact definition of aggression (also known as the crime against peace) in international law is that the offences/crimes have been modernizing day by day, Information Technology (IT) contribute more in this, today conventional war is backed by fifth-generation war e.g. the imposition of restrictions, causing, projecting, propagating rebel against the other state's government, diplomatic ties, non-cooperation, abolishment of trade relations are all to be included in the definition because they are launched against a sovereign state, and it may affect the integrity and sovereignty of the state against whom the attack is launched (Sayapin, 2017).

There are mainly two kinds of internationally recognized aggression one is direct aggression, and the latter is indirect. Direct aggression refers to aggression in which the armed forces of the states participate in the conflict one may say it as a war between two internationally recognized states in which the states supposed to adopt the means that he gained for such an activity like weapons, while indirect aggression is the adoption of other means rather than the armed forces (Garner, 2021). If indirect aggression is analyzed, it seems that it has two prime distinctive meanings. Delict acts armed or unarmed led vicariously by the aggressor state through a third party which risks the essential rights of the state. Unlawful acts carried by the institutions of the government of a state against another state without utilizing the armed forces with the help of a third party, which do endanger the state integrity or sovereignty (Sayapin, 2017). It is evident from the preliminary discussion that the point of jurisdiction to take-up the case of aggression vests with ICC, the signatory states of the Rome Statute may demand the ICC to invoke the jurisdiction on the matter in which the dialogue failed. 


\section{Research methodology}

Looking at the parameters for the purposes of this study, the research involved or planned for research focuses on a variety of resources. Keeping in view of the set objectives this research design was adopted to have greater accuracy and depth analyses of the research study, available secondary data was to be used extensively. The investigator procures the required data through secondary survey methods, different News articles, and the web was used, which were enumerated and recorded. Different journals, books, reports, articles, treaties, public documents, customs, legal maxims, and statutes were also concerned and recorded where needed. The research approach will be based up the Qualitative methods. These methods are adopted for research because it is a library base research which includes National and international books, research articles, international journals, reports, and the published articles. The websites and international books from sites are the main sources for collecting data.

\section{International backings of the crime of aggression and precise history of ICC}

As it is primarily stated that "aggression" has not yet been completely defined, no one claimed or is in the position to claim that he has conclusively defined the term from all perspectives. The research indicated that the crime of aggression has not yet been conclusively defined. The question of invoking jurisdiction is certain and clear. As Article 5 of the Rome Statute providing the authority to the International Court to invoke jurisdiction on the offences committed within its jurisdiction. The jurisdiction can be invoked by the Court itself and it can be approached by the conflicting states, the conflicting states may request the International Court to invoke jurisdiction and sort out the point of conflict between the states, the states are duty bound to implement the decision of the Court. Article-5 of the Rome Statute 2002 is produced as follows:

Crimes within the jurisdiction of the Court: The jurisdiction of the Court shall be limited to the most serious crimes of concern to the international community as a whole. The Court has jurisdiction in accordance with this Statute with respect to the crimes as: the crime of genocide; crimes against humanity; war crimes; and the crime of aggression.

The Court shall exercise jurisdiction over the crime of aggression once a provision is adopted in accordance with articles 121 and 123 defining the crime and setting out the conditions under which the Court shall exercise jurisdiction with respect to this crime. Such a provision shall be consistent with the relevant provisions of the Charter of the United Nations." (ICC, 1998, art. 05). It is evident from the aforementioned discussion that the question of jurisdiction is no more unclear or uncertain, the mother instrument that gave birth to International Criminal Court is the Rome Statute, which commenced its operation from 2002 and after its introduction, the question of jurisdiction of the court is settled. This begins with the consideration to draft a codified offences by the International Law Commission (ILC) in 1949, after the work done of almost a decades, the commission proposed a draft code of crimes/offences, same is presented before the UN General Assembly, at that time the commission did not bother to enumerate a body/court to deal with the trial of offences, it was perceptional that unless the court is established, same can be exercisable by the domestic courts. It was primarily given the task to define and elaborate what aggression really means and what constitutes aggression (UN Resolution 3314 (XXIX), 1954). 
1989 was the year in which the UN General Assembly think out to introduce a new plan sanction "international criminal responsibility of individual and individuals involved in illegal trafficking in drugs whether within the territorial jurisdiction of the country or beyond the international defined border, all of what discussed are to be trialed by the International Criminal Court (UN GA, 1981). The UN General Assembly requested the mentioned commission to recommend a court or tribunal which may have jurisdiction over the offences committed by the individual along with the mechanism to trial the offences, especially cover the individuals involved in the offences of drug peddling (UN GA, 1989). From 1989 to 1994 several sittings held at United Nations General Assembly, the Commission shared its research with the UN General Assembly time and again but more research and appreciation was demanded by the assembly, several meetings held, several researches conducted before the adoption of the draft statute for establishment of ICC, which was prepared and presented by the Special Working Group to the commission which covers international conference of plenipotentiaries assigned the task to homework on the draft statute and to present a convention for the establishment of ICC that is able to try the offences mentioned in the draft code.

The Rome Statute of International Criminal Court (ICC) was adopted and was opened for signature on $17^{\text {th }}$ day of July 1998 and the door of accession was opened for all states till 11 March 2003. The first/inaugurated session of the newly born International Criminal Court at Hague, Netherlands (United Nations Diplomatic Conference). International Criminal Court came into being for conducting the trial of the most serious offenders concerned to the international world. The crimes against which ICC has exclusive jurisdiction to take cognizance include genocide, crimes against humanity, war crimes, and the crime of aggression. As far as the last crime is concerned ICC adopted any provision that defines the term aggression, it shall state the constituent ingredients that tantamount to the crime of aggression, meaning thereby that what and what not includes in the crime of aggression. As the ICC has conclusive jurisdiction on the crimes settled in the code, but the state parties have the responsibilities to bring the most serious offenders of the genocide, crime against humanity, war-booty, and the offenders of aggression before the ICC, so that the unprecedented trial could be conducted, state parties must take reasonable steps to secure their lands from the aforementioned offences (United Nations Diplomatic Conference).

\section{Crime of aggression, the constituent ingredients and a brief history}

The International Criminal Court from July 2018 is exercising its conclusive jurisdiction over the crime of aggression, the court prosecutes the offender/leaders of the states waging aggressive war. The member states of United Nations/parties to the Rome Statute/the mother law of the ICC agreed to confer the powers to prosecute the crime of aggression to the ICC. After that, the crime of aggression is instated there in the jurisdiction of ICC as the $4^{\text {th }}$ core crime. The insertion of the crime of aggression in the Rome Statute strengthen the legislation as well as strengthen the jurisdiction of ICC which ultimately save the world from the immoral and unjustified behavior responsible for such offence and maintained the global order which ultimately based on the supremacy and rule of law (Pace \& Panganiban, 2018). The insertion of aggression in the jurisdiction of ICC is indeed a blessing for the globe, the ICC stands for the conscience and against hatred, violence, and animosity (Trahan, 2016). The crime of aggression has three core important facts:

- The main focus of it is on the most responsible leader of the country who involved himself in the crime of aggression. 
- It is always implied on the individual/leader of the state and not directly on the state.

- The last attribute of it is the $4^{\text {th }}$ core crime on which ICC has conclusive jurisdiction.

After the adoption of the resolution through which the crime of aggression added to the jurisdiction of ICC, a point is raised whether ICC invokes its jurisdiction over all member states of the UN, or the states required to ratify the same from the legislative houses of their own. ICC Rome statute was adopted 20 years before the insertion of the crime of aggression in it, so the aforesaid question arrived. Before going in detail, the definition agreed upon by the member states is to be recalled. The crime of aggression hereby means "the planning, preparation, initiation or execution, by the person having the prominent position to exercise control over the political or military institution of a state, on an aggressive act, which by its character, severity, and scale, constitutes the manifest violation of the charter of United Nations (ICC, 1998, art. 08). The act of aggression is basically the use of military force against the integrity, political independence, and sovereignty of another state and in the manner derogatory to the UN Charter, the acts may include invasion, military takeovers, and annexation of the disputed parts with force and without the prior consent of inhabitants and the stoppage of ports (ICC, 1998, art. 08).

\section{The ways through which International Criminal Court may invoke jurisdiction on the crime of Aggression}

As we all know that there are four classes of offences on which ICC has the jurisdiction to prosecute include genocide, crime against humanity, war crimes, and the crime of aggression. Genocide is being defined in ICC Rome statute as the acts that destroy the racial or ethnic group partly or completely, it may include killing or causing bodily harm that is stuffiest for one's demise (ICC, 1998, art. 06). Crime against humanity includes the acts of murder, extermination, enslavement, etc. when committed as part of a widespread or systematic attack directed against any population or civilization (ICC, 1998, art. 07). War crime as defined in this statute as the gross violation of Geneva Convention 1949 launched against the person or property protected under the convention, may include willful torture, inhuman treatment, extensive mass destruction etc. (ICC, 1998, art. 08). Crime of aggression includes planning, initiation and execution of policy framed out by an individual/leader who is having the position to launch and direct political or military action against the other state (ICC, 1998, art. 08 bis) The Court may invoke jurisdiction on either offence. The proceeding can be initiated on the report/issue presented before the court by either member state, the prosecutor himself may initiate the investigation or the situation is referred by United Nations Security Council before the ICC. In later situation where the UN Security Council bring a matter before the court, it can be a non-member and the court has to invoke the jurisdiction on a non-member state, while on the formal situations, ICC can only invoke the jurisdiction if the matter affecting the member-states regardless of victim or aggressor status.

As far as the art.08 bis of the ICC Rome Statute is concerned, it primarily defined what aggression actually means by endorsing the leadership/individual's responsibility for such commission. Both military and political actions are included in the definition, which hereby means that aggression may be caused politically as well as through military operation. The last portion of definition provided that aggression through its character, gravity and scale tantamount to the gross violation of United Nations Charter. If the provided definition is opened one may find that aggression is an act launched by a state against another state that endanger 
the political independence, sovereignty and territorial integrity and is inconsistent or derogatory to the provisions of United Nations Charter. The acts, regardless of the declaration of war, include attack or invasion of a state on the other state's territory, occupation whether temporary or permanent or annexation. It may include the act of bombing or utilization of weapons by a state against the other. It may also include the blockage of ports by a state against another state. It may also include the attack launched by a state on the land, sea and air of another state, it may also include the stay of armed forces of a state in another state after the expiry of the agreement etc.

On the point of jurisdiction after amendment in Rome Statute, several points of views sustain. The amendment in the ICC Rome Statute regarding the crime of aggression commenced one year after its ratification by the member state. As if the member state activates the Court jurisdiction, the fact of "opt-out" remains on back in the situations in which matter is not brought before the court by the UN Security Council. A reported consolidated view also exists which states that the jurisdiction would be conclusively invoked by the court when minimum 30 member states ratify the amendment in the Rome Statute from their respective legislative bodies and the decision by the Assembly of the States Parties (ASP) (The Coalition for the ICC, 2018). The point of jurisdiction is also highlighted there in the Article-15 of the Rome Statute, which states the exercise of jurisdiction by the International Criminal Court where the state involved in the offence/crime of aggression had not yet ratified the Kampala amendments and not opted-out the jurisdiction of ICC, it is pertinent to mention here that the states hereby means the leader who has the control over the military force and has the power to command the force (Schabas, 2017).

\section{Who is responsible for the crime of aggression?}

After the Nuremberg trial, the term aggression received consideration from the whole world; it has been projected as one of the most serious international crimes. The idea to try an individual who is holding the power and is in the position to command the armed forces for committing the crime of aggression is responsible for what he commands, received appreciation on a large scale. The Assembly of the State Parties adopted the definition of the crime of aggression in 2010 and described the conditions and circumstances on which ICC can invoke jurisdiction over it. The Assembly revealed that the crime of aggression is settled to be given under the jurisdiction of ICC in the early time of 2017; still, it is internationally controversial whether the criminalization of aggression is an upshot to strive for, or whether its abandonment is more preferable. "War is essentially an evil thing. Its consequences are not confined to the belligerent States alone but affect the whole world. To initiate a war of aggression, therefore, is not only an international crime; it is the supreme international crime differing only from other war crimes in that it contains within itself the accumulated evil of the whole" (Rogers, 2018).

"Indeed, no more grave crimes can be conceived of than a conspiracy to wage a war of aggression or the waging of a war of aggression, for the conspiracy threatens the security of the peoples of the world, and the waging disrupts it" (Crowe, 2014). The paragraphs mentioned above are most important as the sufferings of war have been described, war has outcomes far beyond that of one's thinking because it damages humanity ultimately, as the world noticed that World War one starts from the murder of Franz Ferdinand and his wife Sophie by the Philippines National Comrade (Edge, 2015). It surrounded the whole world and caused approximately 15 million people's deaths (EFG, 2013). The damage of the war could not be estimated as after it wages, and it covers not only the belligerents but the whole inhabitants. 
The judgments given on the above-stated cases are essential from each perspective as the judiciary briefly explained each and every perspective of war and warned the world from the sufferings caused by the war and finally stated that the world is not in every case, a result to sort out the conflicts because the war always happens due to the aggression. The Rome statute now contains the provision to prosecute the aggressor/person waging war. ICC would conduct the trial, and now the ICC has the jurisdiction to try the person/leader responsible for aggression (Sewall, 2020). Moreover, according to the United States of America vs. Wilhelm von Leeb and 12 others, hereinafter called as High command case Nuremberg military tribunal held that offenders who have been accused of the crime of aggression must have: "Actual knowledge that aggressive war is being intended and that it will be an aggressive war if launched. It requires in addition that the possessor of such knowledge, after he acquires it, shall be in a position to shape or influence the policy that brings about its initiation or its continuance after its initiation, either by furthering or by hindering or preventing it. If he then does the former, he becomes criminally responsible; if he does the latter to the extent of his ability, then his action shows the lack of criminal intent with respect to such policy." War crime is "War crimes are those violations of international humanitarian law (treaty or customary law) that incur individual criminal responsibility under international law."

\section{Historic touch}

The idea of sovereign state emerged in nearly $16^{\text {th }}$ century, the state became supreme over its subjects within its territorial jurisdiction, this power/authority has long been manipulated by the state stakeholders, and they used it as a hostage to shade their wrongs (Lardon, 2019). They believed that what they are doing, are doing with the name of state and no one held them responsible for their acts, it was the time when international law just recognized states as their subject. When the atrocities enhanced the civil society counter the unlimited powers of the stakeholders. The states at that time did not bother to give considerations to protect, recorded by the civil society and casually launched brutal attack against them, no one dares to ask from them of their immoral and illegal acts. The protest converted into the disobedience movements with the motto to abolish impunity and to replace it with responsibility.

The aggression imposed by the emperors on their subjects crossed the borders due to which the world faced two world wars. After World War-I, the idea to prosecute the individual/leaders responsible for wagging war, aggression was given, and Special Tribunal for Kaiser Wilhelm was established via a treaty of Versailles in 1919. No proceeding was held due to the refusal of the Netherlands to hand over Kaiser to the Allies (Bassiouni \& Schabas, 2016). The credit goes to the Nuremberg International Tribunal for the trial of what we presently called the crime of aggression after world war-II under the name of crime against peace. The definition available in certain international instruments- is planning, initiation, or waging war of aggression or the war that derogates the human rights or international treaties or agreements. The judgment given by the tribunal is having the prime importance; it was held that the crime projected against the provision of international law, committed by the man and not the immaterial bodies like the states and by punishing the leaders responsible for wagging war/aggression absent the other be enforced (Rhea, 2018). The judgment while examines, revealed that there are flaws and shortcoming in it, but the trial effectively wakens up the international bodies and forced them to think about establishing the instruments that are internationally binding. After the judgment of the Tribunal, UN General Assembly appreciated and affirmed the principle laid down and the judgment of the tribunal (Sipowo, 2018). 
After the adoption of United Nations Charter, the essence of criminalizing the responsible individual faded, as UN Charter gave the brief account to resolve the conflicts arise between the countries, it flatly rejected the use of force to sort out the issues (Singh, 2020). Every act that is in derogation of the UN Charter is prohibited to use for resolution of the conflicts (Singh, 2020). The UN gave exception to this article as to why, where, and how force can be used against the rivalry (Von-Verdross, 2020). The promise given by the American Chief Prosecutor in Nuremberg cannot be denied he stated that international law stands against the individuals responsible for aggressive war and all violations of international law in this perspective will be trilled as a crime against peace (Opening Speech). The world is not now in a position to afford a war again, all these steps guarantee that if anyone enters into a war of aggression with the enemy, he would be trialed and punished internationally by the ICC.

\section{Individual criminal responsibility and the crime of aggression}

Before the Kampala conference and the recognition and adoption of the definition of the crime of aggression, the benchmark was the Nuremberg Trial and the Resolution of United Nations General Assembly brought in 1947 (UN GA, 1974). The crime of aggression like any other crime has two constituent ingredients Men's rea and Actus reus the formal is the bad, evil intention, it is a Latin term the plural of which is "mentes reas" a condition of the mind that is required to culminate a person for the commission of the crime. It is established through various judgments of the Apex Courts working all over the world that, the prosecution has the responsibility to prove the case without any shadow of doubt and has to prove the criminal mind/intention which is the main requirement to punish the offender (Staples v. United States). In order to strengthen the argument, the quotation of Justice Homles cannot be neglected, he said, "even the dog is capable to distinguish between being stumbled over and being kicked" Later is Actus reus which hereby refers here is acts of aggression, basically the movement has voluntarily taken which is prohibited or prevented by the society or state (Mens Rea). The Apex Courts all over the world consider it as the main and primary ingredient of the crime without which the person can't be punished merely on the basis of evil intent (Powell v. Texas). The one who held responsible for the commission would be penalized because it's a crime against international; peace which gives rise to international responsibility (UN GA, 1974, art.05 (2)).

The definition of aggression as stated above is provided under Article 1 of the above said resolution as, "the use of military force by a state which derogates the internationally defined sovereignty of other state and off course the violation of UN Charter and the Resolutions of United Nations (UN GA, 1974, art.01). As it is cleared in the preliminary arguments that responsibility cannot be brought on abstract entities, it is imposed on the person giving the command to wage the war. The Nuremberg Tribunal stated clearly that "mens reus is the operative part of crime together with actus rea." (Dinstein, 2017).

Whenever any matter is brought before ICC, the one who brought the matter has the responsibility to prove the allegation on the offender without any shadow of a doubt. As domestically the prosecutor of the Court proves the mens rea and actus rea before the judge during proceedings, and the judge utilizes his mind that the prosecution is succeeded in proving the guilt or failed and pronounced judgment, the same situation is presumed in the trial initiated in front of ICC, the entity which brought a case is held responsible to prove the constituent ingredient of the crime and prove the acquisition on the offender beyond any shadow of doubt. ICC after probing and instigating the matter draw a concluding line whether the prosecution has proven the guilt/acquisition or not and then pronounced the order. 


\section{Comparative analyses of the procedure adopted before the establishment of ICC and after ICC}

The crime of aggression and to hold the individual responsible for wagging aggressive act/war against the other is sorted out in the Rome Statute of International Criminal Court via Article8. It directs that the one who is in the authority to command and control the military force, utilized and commanded it to cause aggression, held responsible for what he commanded and would be trialed before the International Court of Justice. From the said declaration it is cleared that the individual who is not in the position to command the armed forces, neither having the authority to do so, would not be held responsible for his act. If we comparatively analyze the standard adopted by ICC and post-World War II established tribunal, the difference is evident. The procedure adopted by ICC is more comprehensive and defined than that of the procedure adopted by Nuremberg Tribunal etc. the standard that is fixed and definitive for ICC is trial of the person involved in the crime of aggression, who is in the position to give command and direction to his army, meaning thereby the offenders or perpetrators are only those who have the stake, and authority to command the forces on behalf of their state e.g. head of the state. The person executing the command of the head of the state is exempted for what he complied.

The mechanism "control or direct" overlap "shape or influence". The policy though formulated, conspired, planed by the others but ultimately the one who issued a written order to invade/aggression is liable for his acts which he has taken as representative of the state. In shape and influence, the individual is though part and parcel of activity, formulate the policy, formulate the plans he has no authority to pass an order for execution of what is formulated, he needs the assistance of the head person to pass an order for execution of policy framed out by him. Another appealing point is that the person would be held responsible who though do not have any prominent position and are involved in the affairs in the mean, that they have a stake in the order passed by the head for waging aggressive war. The concept of "direct and control" is internationally regained having no practical precedent whether national or on international forums because the criteria of leadership is yet to be determined by the ICC.

\section{Conclusion}

The term aggression is no more unclear and undefined. It has been the center of concern for the United Nations for a long period of time. The UN along with other institutes like International Law Commission formulated the idea to culminate the persons/individually responsible for waging aggressive wars against their rivalries. The scope of states responsibility is abolished by introducing the idea of individual responsibility and stated clearly that whoever in the position to command the military personals commanded for wagging aggression would be trialed before the International Court namely International Criminal Court and after the amendment in the Rome Statute, the mother law, the ICC has the conclusive jurisdiction to trail the crime of aggression. As we all know that during the world wars which state adopted the policy of aggression and impeached the provisions of International Law. Before the Rome Statute, the provisions of international law called customary international law are there to guide the states on how to enter and conduct war against their enemies but neither state bother to adopt that. As far as the initiation of trial and imposition of punishment on the leader clause is concerned, the international community needs to implement the provisions on all states universally, every state even a veto state is responsible under the law to follow the provisions of international law and the judgments and findings of ICC because until the principle of rule of law is not universally observed, the world is no more safe from another war. The 
international community needs to consider one more important issue in order to make the trial more comprehensive, as we all know that it's a general principle of criminal law that "benefit of the doubt is to be given to the accused" as "accused is the favorite child of law" the standards of investigation and trial are to be fixed and evolved so that the precision and accuracy is maintained to culminate whoever proved guilty.

\section{References}

Bassiouni, M. C., \& Schabas, W. A. (Eds.). (2016). The legislative history of the International Criminal Court (2 Vols.): Second revised and expanded edition. Brill. https://doi.org/10.1163/9789004322097

Crowe, D. M. (2014). The Tokyo IMT trial. In War crimes, genocide, and justice (pp. 195241). Springer. https://link.springer.com/chapter/10.1057\%2F9781137037015_7

Dictionary, M. W. (2020). Meaning and definition of aggression. https://www. merriamwebster.com

Dinstein, Y. (2017). War, aggression and self-defence. Cambridge University.

Edge, S. (2015, January 26). The gunshots that change history: Murder of Franz Ferdinand and the start of World War One. Express. https://www.express.co.uk/news/world-war1/485408/WW1-World-War-One-Franz-Ferdinand-centenary

Garner, B. A. (2021). Black's Law Dictionary, (11 ${ }^{\text {th }}$ ed.), St. Paul, Thomson/West.

Heller, K. J. (2020). The Rome Statute of the International Criminal Court. In: The Handbook of Comparative Criminal Law (pp. 593-634). Stanford University. https://doi.org/10.1515/9780804777292-018

ICC. (1998). The Rome Statute of the International Criminal Court. International Criminal Court (ICC). https://legal.un.org/icc/statute/romefra.htm

Lardon, S. (2019). The six books of the republic by Jean Bodin (1576). The first quotation from the Strasbourg Oaths. Corpus Eve. Emergence of Vernacular in Europe. https://journals.openedition.org/eve/1781

McDougall, C. (2021). The crime of aggression under the Rome Statute of the International Criminal Court. Cambridge University. https://doi.org/10.1017/9781108769143

Mens Rea. (rep.). Legal Information Institute. https://www.law.cornell.edu/wex/mens_rea\#: :text=Mens\%20Rea\%20refers\%20to \%20criminal,511\%20US\%20600\%20(1994

Opening Speech of the Chief Prosecutor for the United States, reprinted in trial of German Major War Criminals by the International Military Tribunal Sitting atm Nuremberg Germany Buffalo (2001), William S. Hein \& Co., https://encyclopedia.ushmm.org/content/en/article/international-military-tribunal-atnuremberg

Pace, W. R., \& Panganiban, R. (2018). The power of global activist networks: the campaign for an international criminal court. In Civil Society in the Information Age (pp. 109126). Routledge. https://doi.org/10.4324/9781315186924-8

Powell v. Texas, 392 U.S. 514, 88 S. Ct. 2145, 20 L. Ed. 2d 1254 (1968).

Rhea, H. M. (2018). International Criminal Courts Prior to the Second World War: An historical analysis of International and Multinational Criminal Courts Preceding $\begin{array}{llllll}\text { Nuremberg. Syracuse } \quad J . & \text { Int'l L. \& Com., 46, } 323 .\end{array}$ https://heinonline.org/HOL/LandingPage?handle=hein.journals/sjilc46\&div=12\&id =\&page $=$ 
Rogers, D. (2018). International Military Tribunals. In Law, politics and the limits of prosecuting mass atrocity (pp. 33-56). Palgrave Macmillan. https://doi.org/10.1007/978-3-319-60994-2_2

Schabas, W. A. (2017). The International Criminal Court: A commentary on the Rome statute. Oxford University.

Sewall, S. (2020). The crime of aggression and the responsibility to protect. The International Criminal Court: Contemporary challenges and reform proposals (pp. 270-277). Brill Nijhoff. https://doi.org/10.1163/9789004384095_029

Singh, K. (2020). Law and practice of the United Nations.

Sipowo, A. G. (2018). Claus Kreß and Stefan Barriga (eds), The crime of aggression: A commentary. https://doi.org/10.1093/jicj/mqy013

The Coalition for the ICC. (2018, July 17). The crime of aggression. http://www.coalitionfortheicc.org/explore/icc-crimes/crime-aggression

Trahan, J. (2016). An overview of the newly adopted International Criminal Court definition of the crime of aggression. Journal of International and Comparative Law, 2(1), 3.

Sayapin, S. (2017). The crime of aggression in International Criminal Law. Springer. https://link.springer.com/book/10.1007\%2F978-90-6704-927-6

UN GA. (1974). Definition of Aggression, United Nations General Assembly Resolution 3314 (XXIX). United Nations. http://hrlibrary.umn.edu/instree/GAres3314.html.

UN GA. (1981). Resolutions and decisions adopted by the General Assembly during its 36th session (36/106 IX). United https://research.un.org/en/docs/ga/quick/regular/36.

UN GA. (1981, December 10). Resolutions and decisions adopted by the General Assembly during its 36th session (36/106 IX). United Nations. https://research.un.org/en/docs/ga/quick/regular/36.

UN GA. (1989). Resolutions and decisions adopted by the General Assembly during its $44^{\text {th }}$ session (44/39). United Nations. https://research.un.org/en/docs/ga/quick/regular/44

UN. (1954). General Assembly documentation, reports, resolutions, decisions, meeting records. United Nations. https://research.un.org/en/docs/ga/quick/regular/9.

United Nations diplomatic conference of Plenipotentiaries on the establishment of an International Criminal Court (1998: Rome. (2002). United Nations diplomatic conference of Plenipotentiaries on the establishment of an International Criminal Court, Rome, 15 June-17 July 1998: Official Records. United Nations.

Von-Verdross, A. (2020). The Charter of the United Nations and General International Law. In Law and Politics in the World Community (pp. 153-161). University of California. https://doi.org/10.1525/9780520349568-012 